\title{
Assessing the phytoremediation potential of a flowering plant Zinnia angustifolia for arsenic contaminated soil
}

\author{
Poonam \& S. Srivastava \\ Institute of Environment and Sustainable Development, Banaras Hindu University, Varanasi, India
}

\begin{abstract}
Arsenic (As)-based chemicals, insecticides, herbicides, rodenticides and irrigation with As containing water have resulted in As contamination in farmland, lawns and residential areas. This study focused on phytoremediation potential of a seasonal flowering plant Zinnia angustifolia for As removal from contaminated soil. Plants were subjected to As stress $\left(100 \mathrm{mg} \mathrm{kg}^{-1}\right.$ soil) in field conditions for 60 days and their tolerance was evaluated through growth and antioxidant assays. Root tissue was found to accumulate more As (1085.42 $\mu \mathrm{g} \mathrm{g}^{-1}$ dry weight (DW)) in comparison to shoot $\left(279.28 \mu \mathrm{g} \mathrm{g}^{-1} \mathrm{DW}\right)$ and flowers $\left(228.67 \mu \mathrm{g} \mathrm{g}^{-1} \mathrm{DW}\right)$ at $60 \mathrm{~d}$.
\end{abstract}

\section{INTRODUCTION}

About 100 million people, living in 23 countries are exposed to As toxicity. In Bengal delta (comprising of West Bengal, India and Bangladesh), source of As pollution is geogenic. The extraction of toxic metalloid pollutants from contaminated soil and water is needed. There are various physical, chemical and biological methods available. However, the expensive high-tech remedial measures are not easy for developing countries like India and Bangladesh; hence emphasis has to be on remediation by cost-effective methods. Phytoremediation fulfills these requirements as it is costeffective solar driven technology for metal removal (Chen et al., 2015; Reed et al., 2015). Ornamental and flowering plants have not been much investigated for phytoremediation potential of As contaminated soils. Flowering plants can help in reclamation of contaminated land and through production of cut flowers and other marketable commodities (Srivastava et al., 2007, 2011). This can manage the cost involved in the phytoremediation for farmers. These plants can also provide an aesthetic value to people and surrounding locality on contaminated sites.

\section{METHODS}

\subsection{Soil preparation and nursery development}

The plant used in the study is zinnia (Zinnia angustifolia). To achieve the set objective, pot experiments were performed. Soil preparation was done a month before. Soil was crushed and filtered to get fine particles so that As $\left(100 \mathrm{mg} \mathrm{kg}^{-1}\right)$ can be equally mixed. All the experiments were carried out in the poly house under control conditions and duration of experiment was $60 \mathrm{~d}$ from transplanting to harvest at $20 \mathrm{~d}$ intervals $(20,40$ and $60 \mathrm{~d})$. Plant nursery was developed and healthy plants of equal heights $(30 \mathrm{~d}$ old $)$ from the nursery were selected for the experiment. In due course of time, the soil was under incubation and was mixed regularly so that As got homogenously distributed in soil. Triplicate set of pots were used for the control and As treatments for the experiment.

\subsection{Growth, enzyme and metabolite assays and arsenic analysis}

Plant growth parameters like fresh biomass and shootroot growth in term of length were measured. Plants samples (root, shoot and flowers) were oven dried and acid digested for As estimation. Arsenic concentration was determined by inductively coupled plasma mass spectrometer (ICP-MS; Agilent7500 cx). The standard references materials were used for calibration and quality assurance for each analytical batch. For accuracy, repeated analysis $(n=10)$ of quality control samples was done, and the results were found within the certified values. Fresh plant sample were crushed in liquid $\mathrm{N}_{2}$ and used for chlorophyll analysis and enzyme extraction by following standard protocols and readings were taken using spectrophotometer.

\section{RESULTS AND DISCUSSION}

\subsection{Plant growth and physiological response}

Zinnia plants grown in As treated soil were observed to have shorter root $(2.16 \mathrm{~cm})$ and shoot $(3.07 \mathrm{~cm})$ length as compared with plant grown in control soil $($ shoot $=15.00-29.40 \mathrm{~cm}$, root $=8.46-14.00 \mathrm{~cm})$. Flower bud appeared between 20 to $40 \mathrm{~d}$ and control plants showed maximum number of flower buds. Total number of fresh leaves also varied at different 


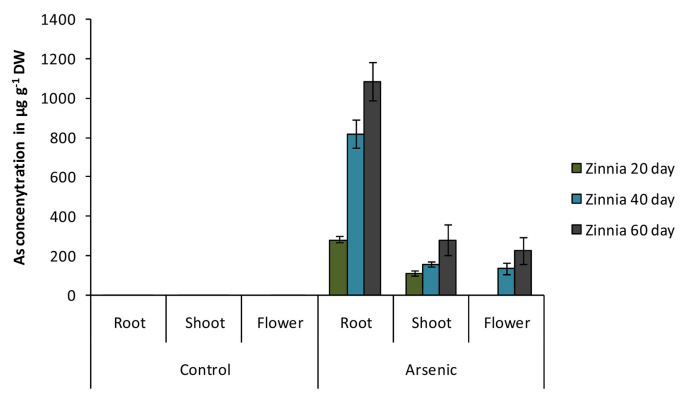

Figure 1. Arsenic removal by zinnia during 1-60 day of growing period.

Table 1. Cysteine content ( $\left.\eta \mathrm{mol} \mathrm{g} \mathrm{g}^{-1} \mathrm{FW}\right)$ observed in different parts of zinnia.

\begin{tabular}{lllll}
\hline \multicolumn{2}{l}{ Cysteine content } & & & \\
\hline & & Root & Shoot & Flower \\
\hline \multirow{2}{*}{$20 \mathrm{~d}$} & Control & 33.80 & 22.41 & - \\
& Arsenic & 22.72 & 38.52 & - \\
$40 \mathrm{~d}$ & Control & 32.83 & 22.23 & - \\
& Arsenic & 20.44 & 30.92 & - \\
$60 \mathrm{~d}$ & Control & 30.15 & 21.34 & 17.47 \\
& Arsenic & 18.39 & 27.68 & 16.97 \\
\hline
\end{tabular}

harvesting time between control and As treated plants. Roots from the treatments were prone to damage and break as compared with control plants. Roots were hard and easily breakable in As treated plants. Roots showed high As accumulation in comparison to shoots (Fig. 1).

\subsection{Biochemical parameters}

To analyze the effect of As on biochemical parameters of plants; chlorophylls, enzymatic and non-enzymatic parameters were assayed. Chlorophyll content of zinnia in As treated soil was higher as compared to control plants at 20 and $40 \mathrm{~d}$ and decreased at $60 \mathrm{~d}$. Ascorbate peroxidase (APX) and guaiacol peroxidase (GPX) activities were reported to increase with each harvesting time in As treated plants as compared to control plants. Cysteine content was decreased in roots while increased in shoot in As treated plants as compared to that in control plants on all durations (Table 1). In case of proline content, it was reported less in treated plants than the control in both root and shoot of plants during $60 \mathrm{~d}$ of exposure. But with increasing toxicity, proline was found to increase with highest value at $60 \mathrm{~d}\left(\mathrm{root}=9.39\right.$ and shoot $=3.61 \mathrm{mg} \mathrm{g}^{-1}$ fresh weight $(\mathrm{FW}))$ in As treated plants.

\section{CONCLUSIONS}

From our study based on arsenic tolerance analysis of zinnia, it was found that plant was able to grow under $100 \mathrm{mg} \mathrm{kg}^{-1} \mathrm{As}$ in soil. The stress caused by As was evident in terms of growth reduction. However, it could be tackled effectively by the increase in antioxidant enzyme like APX and GPX activity in root and shoot and important metabolites like cysteine. Overall, the use of flowering plants could offer a viable approach of not only making contaminated site aesthetic and reclaimed but also decontaminating that with time. The major benefit with flowering plants is their nonedible nature and hence this would pose no risk of any contamination to humans.

\section{ACKNOWLEDGEMENTS}

Authors gratefully acknowledge the support from funding received from DST-SERB (GOI) under Young Scientist Award (project code: P07/610).

\section{REFERENCES}

Chen, G., Liu, X., Brookes, P.C. \& Xu, J. 2015. Opportunities for phytoremediation and bioindication of arsenic contaminated water using a submerged aquatic plant: Vallisneria natans (Lour.) Hara. Int. J. Phytoremediation 17(3): 249-255.

Reed, S.T., Ayala-Silva, T., Dunn, C.B. \& Gordon, G.G. 2015. Effects of arsenic on nutrient accumulation and distribution in selected ornamental plants. Agric. Sci. 6(12): 1513-1531.

Srivastava, S., Mishra, S., Tripathi, R.D., Dwivedi, S., Trivedi, P.K. \& Tandon, P.K. 2007. Phytochelatins and antioxidant systems respond differentially during arsenite and arsenate stress in Hydrilla verticillata (L.f.) Royle. Environ. Sci. Technol. 41(8): 2930-2936.

Srivastava, S., Shrivastava, M., Suprasanna, P. \& D'souza, S.F. 2011. Phytofiltration of arsenic from simulated contaminated water using Hydrilla verticillatain field conditions. Ecol. Eng. 37(11): 1937-1941. 